\title{
ULTRASONICALLY ASSISTED ULTRAFILTRATION OF WHEY SOLUTION
}

\author{
MARIETTA ÁBEL, ZSOLT LÁSZLÓ KISS, SÁNDOR BESZÉDES, CECILIA HODÚR, \\ GÁBOR KESZTHELYI-SZABÓ and ZSUZSANNA LÁSZLÓ ${ }^{1}$
}

Department of Process Engineering, Faculty of Engineering, University of Szeged, Moszkvai krt. 9., Szeged H-6725, Hungary

\author{
${ }^{1}$ Corresponding author. TEL: 0036-62-546561; \\ FAX: 0036-62-546549; \\ EMAlL: zsizsu@mk.u-szeged.hu
}

Received for Publication June 2, 2014

Accepted for Publication August 20, 2014

doi:10.1111/jfpe.12177

\begin{abstract}
The ultrafiltration of whey solutions is a common feature of dairy processes. However, the frequent fouling of ultrafiltration membranes and the subsequent cleaning cycle significantly affects the economics of the process. In this work, we investigated the effect of ultrasonically assisted ultrafiltration. The ultrafiltration of whey solution was investigated in order to determine the main parameters affecting the flux, retention and membrane fouling. The experiments were carried out with an ultrasonic combined laboratory ultrafiltration device, using regenerated cellulose ultrafiltration membranes. The results showed that increasing resistance during filtration is predominantly caused by the concentration polarization, while the participation of membrane fouling in the total resistance is negligible. The ultrasonically assisted ultrafiltration actively reduces the concentration polarization layer resistance. The retention changed slightly with ultrasound power.
\end{abstract}

\section{PRACTICAL APPLICATIONS}

Combination of ultrasound and ultrafiltration processes in dairy industry may enhance the efficiency of whey separation processes during ultrafiltration of why solutions. The given model for describing the filtration mechanism and modified Reynolds number for ultrasonically assisted batch reactor allow the scale up of coupled ultrafiltration process for dairy industry.

\section{INTRODUCTION}

Ultrafiltration (UF) is frequently used in the dairy industry for the concentration of whey, which may cause water pollution. The membranes foul during the UF process as the retained particles accumulate on the membrane surface causing a significant reduction in the separation efficiency by decreasing the permeate flux and increasing the pressure drop across the membrane (Muthukumaran et al. 2004, 2005). To reduce the rapid flux decline caused by concentration polarization and membrane fouling, cleaning of the membrane surface is necessary. The typical methods for membrane cleaning which have been used practically include backwashing, gas sparging and chemical cleaning. However, these techniques interrupt the continuous filtration process, leading to a longer processing time and the chemicals sometimes damage the membrane materials and cause secondary pollution. Recently, ultrasound has also been used to improve the permeate flux and recovery of membrane permeability (Chai et al. 1999; Kyllönen et al. 2005; Latt and Kobayashi 2006). Coupling microfiltration or UF with ultrasonic irradiation has been shown to be effective in reducing fouling problems (Feng etal. 2011). The enhancement of permeate flux by ultrasonication (US) could be improved using higher ultrasonic intensity and lower ultrasonic frequency (Kobayashi et al. 1999, 2003).

The aims of this work were to investigate and to model the combination of UF and US and to determine the membrane filtration parameters and the mechanism of fouling.

\section{MATERIAL AND METHODS}

\section{Ultrafiltration of Whey Solutions}

Model solutions with whey concentration of 2 wt \% were prepared from instant whey powder. The membrane filtration experiments were carried out in a batch stirred cell 


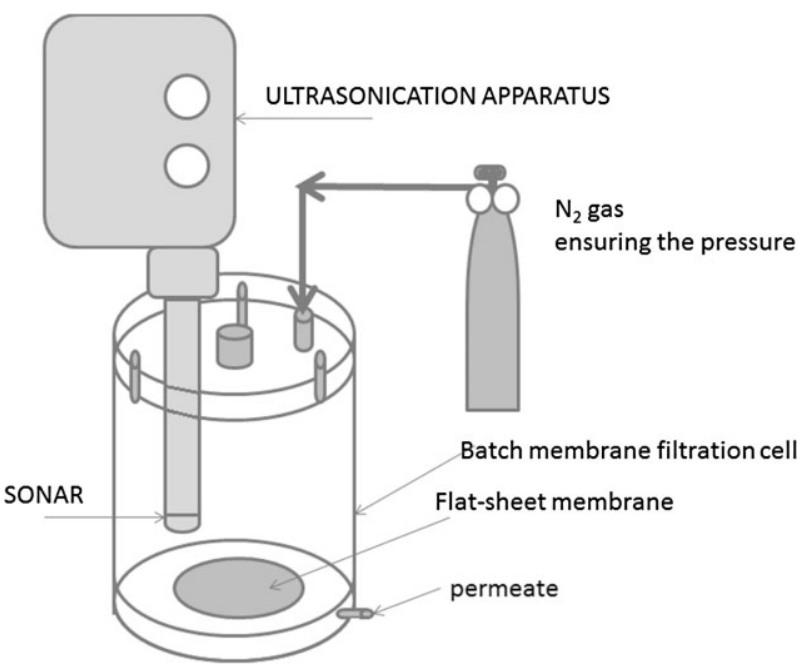

FIG. 1. EXPERIMENTAL DESIGN FOR ULTRASONICALLY ASSISTED ULTRAFILTRATION

(Merck Millipore, Darmstadt, Germany, Serial Nº96) which was built together with an ultrasonic mixer (Fig. 1).

Flat-sheet regenerated cellulose membranes of Amicon (PL series, Merck Millipore, Darmstadt, Germany) with molecular weight cut-offs (MWCO; 3 or $100 \mathrm{kDa}$ ) and a membrane effective area of $0.00418 \mathrm{~m}^{2}$ were used. The capacity of the batch cell is $400 \mathrm{~cm}^{3}$ and the diameter of the membrane is $0.076 \mathrm{~m}$. Before the UF experiment, the membrane was left immersed in distilled water overnight. The initial feed volume was $200 \mathrm{~cm}^{3}$ and experiments were carried out at $100 \mathrm{kPa}$, the pressure was ensured with $\mathrm{N}_{2}$ gas. The measurements were performed in triplicate, in each run a new membrane was used. The sonication experiments were carried out with a US apparatus (UP $100 \mathrm{H}$ Ultrasonic processor, Hielscher Ultrasonics $\mathrm{GmbH}$, Teltow, Germany) with different amplitude $\mathrm{A}_{U S}=20 \%$ and $30 \%$ in continuous mode. The maximal power of the ultrasonic apparatus is $100 \mathrm{~W}$, it was operated at $30 \mathrm{kHz}$.

Diffusion coefficients were determined at 20C with an Armfield CERb apparatus (Armfield Ltd, Ringwood, Great Britain). A specially designed diffusion cell (1) is mounted on top of the stirred vessel and clamped into the desired position using the locking screw. The equipment consists of a variable speed magnetic stirrer (4) and stirring bar (3) for agitation of the test solution (2). The Diffusion apparatus (Fig. 2) uses vertical capillaries $5 \mathrm{~mm}$ long with a diameter of $1 \mathrm{~mm}$, which restricts the diffusion to one dimension. The concentration at the lower ends is assumed constant and the concentration at the top ends is effectively zero during the experiment. The diffusion coefficient was determined on the basis if Fick's law by the Eqs. (1) and (2).

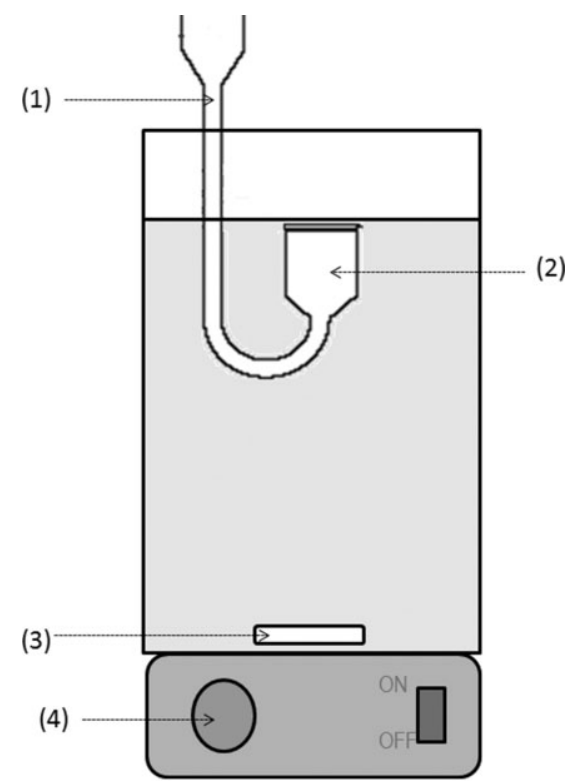

FIG. 2. EXPERIMENTAL APPARATUS FOR DETERMINATION OF DIFFUSION COEFFICIENT [DIFFUSION CELL (1), TEST SOLUTION (2), STIRRING BAR (3), A VARIABLE SPEED MAGNETIC STIRRER (4) (ARMFIELD LTD 2011)]

$$
\begin{gathered}
\frac{V}{C_{M}} \cdot \frac{d k}{d t}=-D \frac{d^{2} \pi}{4} \cdot N \cdot \frac{c_{0}}{x} \\
D=-\frac{4 \cdot V \cdot x}{d^{2} \pi N c_{0} C_{M}} \frac{d k}{d t}
\end{gathered}
$$

where $V$ is volume of water in outer vessel in liters $(\mathrm{L}), x$ is the length of capillaries $(\mathrm{cm}), d$ is the diameter of capillaries $(\mathrm{cm}), N$ is the number of capillaries $(n=121), c_{0}$ is the concentration of the whey solution, $\left(\mathrm{g} / \mathrm{dm}^{3}\right), C_{M}$ is the turbidity change for unit concentration change, $\left(\mathrm{NTU} / \mathrm{g} / \mathrm{dm}^{3}\right), \frac{d k}{d t}$ is the rate of change of turbidity with time, (NTU/s).

Measurements were carried out with $20 \%$ whey solution by measuring the change of turbidity in distilled water. The measurements were performed in triplicate, the diffusion coefficient at $20 \mathrm{C}$ was found to be $2.75 \cdot 10^{-10} \pm 6.48 \cdot 10^{-12} \mathrm{~m}^{2} / \mathrm{s}$.

Viscosity measurements were made with an AND SV-10 vibro-viscometer (A\&D Company Ltd, Tokyo, Japan) in a temperature-controlled water bath (Cole-Parmer, Vernon Hills, Illinois, USA) maintained at $20.0 \pm 0.1 \mathrm{C}$. The sensor plates operate with a low frequency of $30 \mathrm{~Hz}$ and an amplitude of less than $1 \mathrm{~mm}$; the apparatus can measure accuracy of $1 \%$ (repeatability) over the range of $0.3-10,000 \mathrm{mPa} \cdot \mathrm{s}$. The density of each solution was measured at 20C with a Densiti 30PX digital density meters (Mettler Toledo, Tokyo, Japan). The turbidity was measured with a Hach Turbidimeter (Hach, Loveland, Colorado, USA). 
TABLE 1. FILTRATION LAWS

\begin{tabular}{|c|c|c|c|c|}
\hline \multirow{2}{*}{$\begin{array}{l}\text { Fouling mechanism } \\
\text { Complete pore blocking } \\
\text { Gradual pore blocking } \\
\text { (standard } \\
\text { pore blocking) }\end{array}$} & \multicolumn{2}{|l|}{ Filtration law } & \multicolumn{2}{|c|}{$\begin{array}{l}\text { Constant pressure filtration } \\
J_{0} A=\text { constant }\end{array}$} \\
\hline & $\begin{array}{l}J=J_{0} e^{-K_{b} t} \\
J=J_{0}\left(1+\frac{1}{2} K_{S}\left(A \cdot J_{0}\right)^{0.5} \cdot t\right)^{-2}\end{array}$ & $\begin{array}{l}\text { (3) } \\
\text { (4) }\end{array}$ & $\begin{array}{l}\ln J=\ln J_{0}-k_{b} \cdot t \\
\frac{1}{\sqrt{J}}=\frac{1}{\sqrt{J_{0}}}+k_{s} \cdot t \\
k_{s}=0.5 K_{s} A^{0.5}\end{array}$ & $\begin{array}{l}\text { (7) } \\
\text { (8) }\end{array}$ \\
\hline Intermediate filtration & $J=J_{0} \cdot\left(1+K_{i} \cdot A \cdot J_{0} \cdot t\right)^{-1}$ & (5) & $\begin{array}{l}\frac{1}{J}=\frac{1}{J_{0}}+k_{i} \cdot t \\
k_{i}=K_{i} A\end{array}$ & (9) \\
\hline Cake filtration & $J=J_{0}\left(1+2 K_{c}\left(A \cdot J_{0}\right)^{2} \cdot t\right)^{-0.5}$ & (6) & $\begin{array}{l}\frac{1}{J^{2}}=\frac{1}{J_{0}^{2}}+k_{c} \cdot t \\
k_{c}=2 K_{c} A^{2}\end{array}$ & (10) \\
\hline
\end{tabular}

\section{Theory}

The widely used models of fouling mechanisms are cake filtration, intermediate filtration, standard pore blocking and complete pore blocking ( $\mathrm{Hu}$ and Scott 2008; Banerjee and De 2012) and are formulated in terms of flux per unit of time (Table 1).

In Eqs. (3)-(10), $J$ is the flux, $J_{0}$ is the initial flux, the various $k$ are the fouling coefficients and $A$ is a constant. In Eq. (10), $A$ can be expressed as

$$
A=\sqrt{\frac{k_{c}}{2 K_{c}}}
$$

The various $K$ terms are the mass transfer coefficients for the associated filtration laws.

In a stirred batch cell, the solute mass transfer coefficient can be calculated from the following correlations (Nicolas et al. 2000; Jadhav et al. 2001)

$$
K_{c}=0.0443 \frac{D}{b} \cdot \operatorname{Re}^{0.75} \cdot S c^{0.33} \text { if } R e>3,200
$$

where $\operatorname{Re}=\frac{\omega \cdot b^{2} \cdot \rho}{\eta}, S c=\frac{\eta}{\rho \cdot D}$ and $b$ is the stirring radius, $\omega$ is the stirring velocity (in $\mathrm{rad} / \mathrm{s}$ ) and $D$ is the diffusion coefficient (in $\mathrm{m}^{2} / \mathrm{s}$ ).

As this Reynolds number cannot be used in the ultrasonically mixed cell, an equivalent Reynolds number was calculated (Santhanama and Bakhshi 1968) by measuring the equivalent stirring velocity, resulting in the same fluxes as in an ultrasonically mixed UF batch cell. In these cases, the characteristic radius was the radius of the membrane. It was found that the effect of $\mathrm{A}_{\mathrm{US}}=20 \%$ and $30 \%$ ultrasonic mixing is the same as stirring with $n=270 \mathrm{~min}$ and $660 \mathrm{~min}$ and $650 \mathrm{~min}$ and 1,000 min rev in the case of 3 and $100 \mathrm{kDa}$ membranes, respectively.

With the assumption of a convection-diffusion mechanism during filtration, the flux is generally expressed by a simplified equation (Schwarze et al. 2010):

$$
J=K_{c} \cdot \ln \left(\frac{c_{M}-c_{P}}{c_{F}-c_{P}}\right)
$$

where $c_{M}$ is the concentration on the membrane surface, $c_{P}$ is the permeate concentration, $c_{F}$ is the feed concentration and $J$ is the flux. The polarization layer concentration was calculated according to the following equation

$$
c_{M}=\left(c_{F}-c_{P}\right) e^{\frac{J_{c}}{K_{c}}}+c_{P}
$$

The membrane resistance was calculated as (Kertész et al. 2012)

$$
R_{M}=\frac{\Delta p}{J_{w} \eta_{w}} \quad\left[m^{-1}\right]
$$

where $R_{M}$ is the membrane resistance, $\Delta p$ is the pressure difference between the two sides of the membrane $(\mathrm{Pa}), J_{W}$ is the water flux of the clean membrane and $\eta_{W}$ is the viscosity of the water $(\mathrm{Pa} \cdot \mathrm{s})$.

The fouling resistance was determined by measuring the water flux through the membrane after the UF and rinsing it with deionized water to remove any particles of residue layer from the surface by subtracting the resistance of the clean membrane:

$$
R_{F}=\frac{\Delta p}{J_{W A} \eta_{W}}-R_{M}
$$

where $J_{W A}$ is the water flux after the concentration test. The resistance of the polarization layer can be calculated as

$$
R_{G}=\frac{\Delta p}{J_{C} \eta_{W W}}-R_{F}-R_{M}
$$

where $R_{G}$ is the polarization layer resistance $\left(\mathrm{m}^{-1}\right), R_{F}$ is the fouling resistance (mainly resulting from the fouled pores) $\left(\mathrm{m}^{-1}\right), J_{c}$ is the constant flux at the end of the concentration and $\eta_{w w}$ is the wastewater viscosity.

$R T$, the total resistance $\left(\mathrm{m}^{-1}\right)$, can be evaluated from the steady-state flux using the resistance-in-series model: 

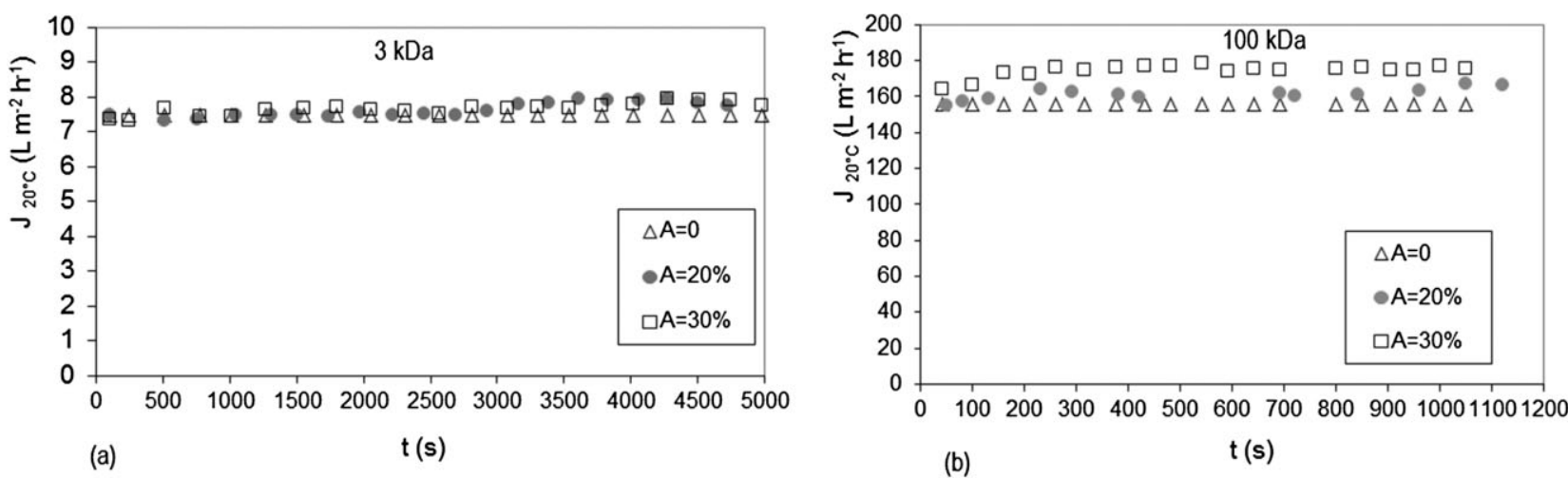

FIG. 3. (A) WATER FLUXES OF REGENERATED CELLULOSE 3 KDA MEMBRANES WITH AND WITHOUT ULTRASONICATION. (B) WATER FLUXES OF REGENERATED CELLULOSE 100 KDA MEMBRANES WITH AND WITHOUT ULTRASONICATION

$$
R_{T}=R_{M}+R_{F}+R_{P}
$$

\section{RESULTS AND DISCUSSION}

\section{US Caused Flux Changing}

In the first series of experiments, the effects of the ultrasonic process on the clear water flux were examined. As the ultrasonic treatment cause warming of the solution, in order to examine the effect of US, the fluxes were normalized to 20C (Fig. 3).

It was found that the water fluxes through the membrane were not affected by US in case of $3 \mathrm{kDa}$ membrane, but in case of $100 \mathrm{kDa}$, the water fluxes slightly increased by US. This phenomenon can probably be explained by the fact that acoustic streaming and/or cavitation causes turbulence, which may cause decreased friction of water in membrane pores, resulting in increased water permeability. On the other hand, this phenomenon can only be observed during sonication. The water flux decreased back to the value measured in an unstirred cell when the sonication stopped, indicating that the membrane was not damaged during sonication.

\section{Whey Solution Filtration}

In the next series of experiments, whey solution with $2 \mathrm{wt}$ $\%$ dry whey content was filtered through membranes with 3 and $100 \mathrm{kDa}$ cut-off weights in unstirred, stirred and ultrasonically mixed batch cells. The linearized filtration laws (Eqs. 7-10) were plotted to measured data and the best correlation was achieved by plotting the cake filtration model. This showed that the UF of whey is gel layer controlled throughout in all cases.

On the basis of Eqs. (11)-(13), the mass transfer coefficients and the fluxes of the cake filtration model were calcu- lated. As Figs 4 and 5 and Tables 2 and 3 show, the simulated flux data are in good correlation with measured data.

The mass transfer coefficients in stirred or ultrasonically mixed cells show that the mass transfer coefficient increases with increasing ultrasound intensity. The $\mathrm{k}_{\mathrm{c}}$ fouling coefficient decreased with membrane pore size, stirring and ultrasonic intensity.

The calculated concentration on the surface of the membrane $\left(c_{M}\right)$ (Tables 2 and 3 ) increased with membrane pore size: this phenomenon can be explained by the convectiondiffusion mechanism of the process. The concentration in the polarization layer is proportional to $J / K_{c}$ (Eq. 14); because the stabilized fluxes at lower MWCO are very low, the diffusion from the polarization layer to the feed solution

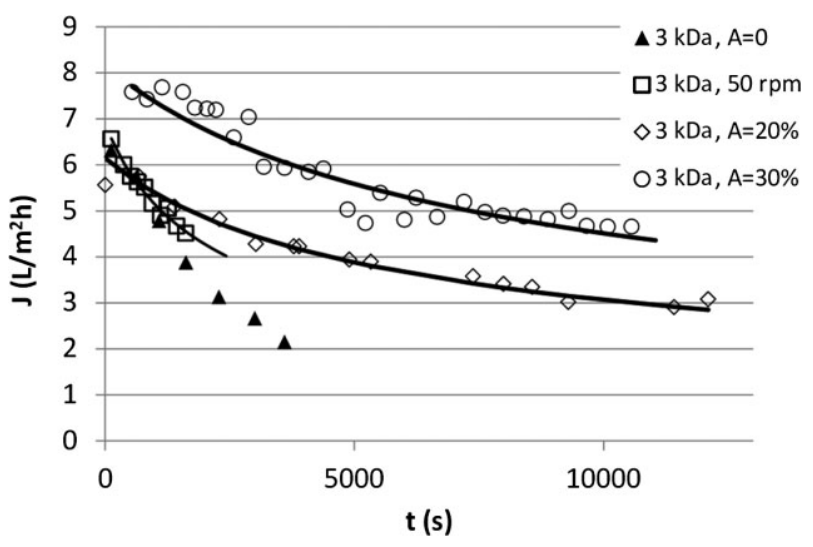

FIG. 4. TYPICAL CURVES OF FLUXES AS A FUNCTION OF TIME DURING ULTRAFILTRATION OF 2\% WHEY SOLUTION ON 3 KDA REGENERATED CELLULOSE MEMBRANES WITH AND WITHOUT STIRRING OR ULTRASONICATION. THE CONTINUOUS LINES REPRESENT THE CALCULATED FLUXES ON THE BASIS OF EQ. (10), THE TABLE 2 SHOWS THE CALCULATED FOULING AND MASS TRANSFER COEFFICIENTS 


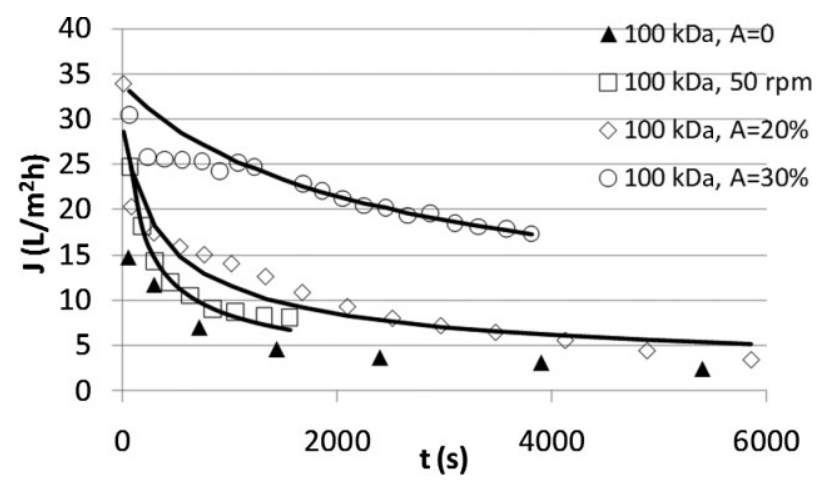

FIG. 5. TYPICAL CURVES OF FLUXES AS A FUNCTION OF TIME DURING ULTRAFILTRATION OF 2\% WHEY SOLUTION ON 100 KDA REGENERATED CELLULOSE MEMBRANES WITH AND WITHOUT STIRRING OR ULTRASONICATION. THE CONTINUOUS LINES REPRESENT THE CALCULATED FLUXES ON THE BASIS OF EQ. (10), THE TABLE 3 SHOWS THE CALCULATED FOULING AND MASS TRANSFER COEFFICIENTS

TABLE 2. CALCULATED MASS TRANSFER COEFFICIENTS AND FOULING COEFFICIENTS IN A STIRRED OR ULTRASONICALLY MIXED BATCH CELL USING 3 KDA ULTRAFILTRATION MEMBRANE

\begin{tabular}{lllll}
\hline Ultrasonication intensity, & & & & \\
W/m & $K_{c}(\mathrm{~m} / \mathrm{s})$ & $k_{c}\left(\mathrm{~m}^{4} / \mathrm{L}^{6} / \mathrm{h}\right)$ & $R \%$ & $C_{M}(\mathrm{wt} \%)$ \\
\hline Unstirred cell & - & $5.28 \cdot 10^{-5}$ & 99.37 & - \\
Aus $=0, n=50 \mathrm{rpm}$ & $3.97 \cdot 10^{-6}$ & $2.05 \cdot 10^{-5}$ & - & 3.64 \\
Aus $=20 \%$ & $2.56 \cdot 10^{-5}$ & $8.00 \cdot 10^{-6}$ & 98.50 & 4.07 \\
Aus $=30 \%$ & $3.75 \cdot 10^{-5}$ & $3.41 \cdot 10^{-6}$ & 96.57 & 4.06 \\
\hline
\end{tabular}

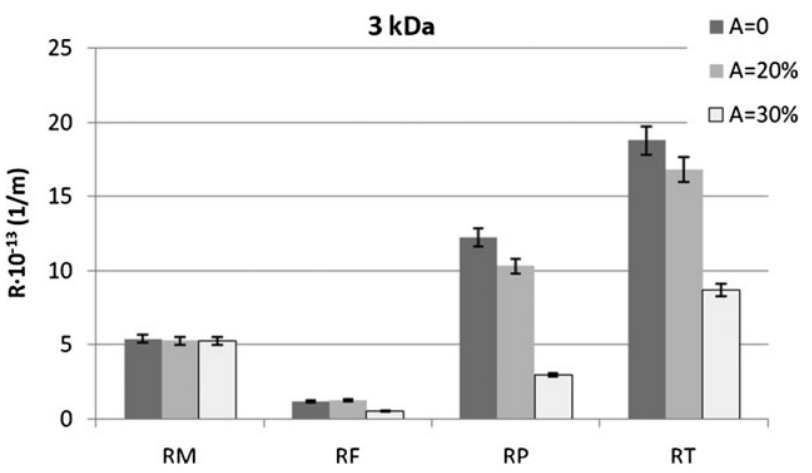

FIG. 7. FILTRATION RESISTANCES DURING ULTRAFILTRATION OF 2 WT $\%$ WHEY SOLUTION IN UNSTIRRED AND ULTRASONICALLY MIXED BATCH CELLS USING A 3 KDA ULTRAFILTRATION MEMBRANE

is more expressed, while convection is the major mechanism at higher fluxes. On the other hand, in the case of $100 \mathrm{kDa}$ membranes, the ultrasound decreased the $\mathrm{c}_{\mathrm{M}}$, probably because of decreased retention.

The calculated retention from turbidity decreased with increasing MWCO but it remained above $90 \%$ in all cases, as shown in Fig. 6.

Filtration resistances were calculated through the use of Eqs. (15)-(18). The membrane resistances $\left(R_{M}\right)$, fouling resistances $\left(R_{F}\right)$, polarization layer resistances $\left(R_{P}\right)$ and total resistances $\left(R_{T}\right)$ presented in Figs 7 and 8 . reveal that the resistance is mainly because of the build-up of a polarization layer and the polarization layer resistance decreases with US intensity, both in the case of 3 and $100 \mathrm{kDa}$ membranes. A comparison of the calculated $R_{T}$ and the $k_{c}$
TABLE 3. CALCULATED MASS TRANSFER COEFFICIENTS AND FOULING COEFFICIENTS IN A STIRRED OR ULTRASONICALLY MIXED BATCH CELL USING 100 KDA ULTRAFILTRATION MEMBRANE

FIG. 6. RETENTION VALUES DURING ULTRAFILTRATION OF 2\% WHEY SOLUTION ON 3 KDA (A) AND 100 KDA (B) REGENERATED CELLULOSE MEMBRANES WITH AND WITHOUT ULTRASONICATION

\begin{tabular}{lllll}
\hline Ultrasonication intensity, & & & $k_{c}\left(\mathrm{~m}^{4} / \mathrm{L}^{6} / \mathrm{h}\right)$ & $C_{M}(\mathrm{wt} \%)$ \\
W/m $\mathrm{m}^{2}$ & $\mathrm{~K}_{\mathrm{c}}(\mathrm{m} / \mathrm{s})$ & $\left(\mathrm{m}^{4} / \mathrm{L}^{6} / \mathrm{h}\right)$ & $100 \mathrm{kDa}$ & $100 \mathrm{kDa}$ \\
\hline Unstirred cell & - & $5.28 \cdot 10^{-5}$ & $3.12 \cdot 10^{-5}$ & - \\
A us $=0, \mathrm{n}=50 \mathrm{rpm}$ & $3.97 \cdot 10^{-6}$ & $2.05 \cdot 10^{-5}$ & $1.37 \cdot 10^{-5}$ & 7.10 \\
Aus $=20 \%$ & $2.56 \cdot 10^{-5}$ & $8.00 \cdot 10^{-6}$ & $6.34 \cdot 10^{-6}$ & 4.29 \\
Aus $_{\text {u }}=30 \%$ & $3.75 \cdot 10^{-5}$ & $3.41 \cdot 10^{-6}$ & $6.43 \cdot 10^{-7}$ & 4.48 \\
\hline
\end{tabular}

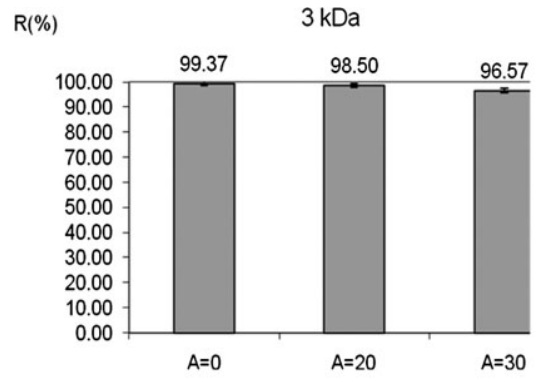

(a)

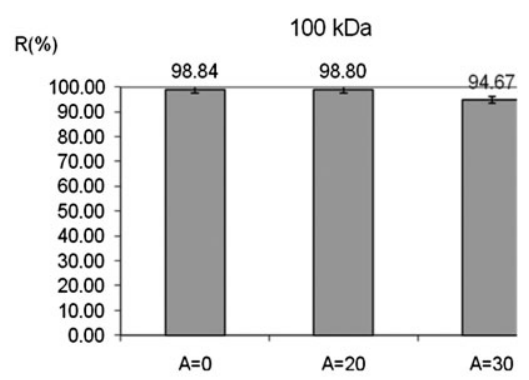

(b) 


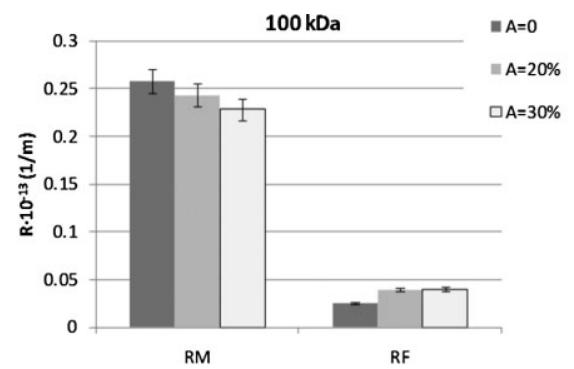

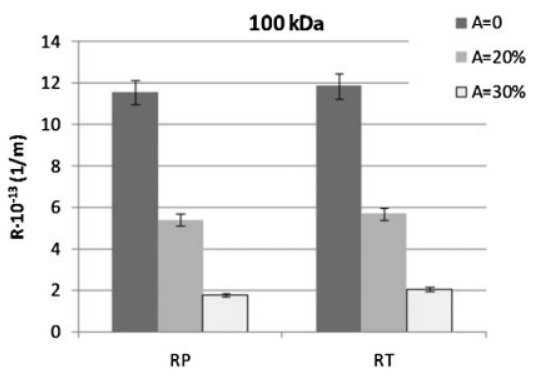

FIG. 8. FILTRATION RESISTANCES DURING ULTRAFILTRATION OF A 2 WT \% WHEY SOLUTION IN UNSTIRRED AND ULTRASONICALLY MIXED BATCH CELLS USING A 100 KDA ULTRAFILTRATION MEMBRANE indicated that these parameters decreased in parallel with increasing ultrasound intensity.

The analysis of variance tests were performed to understand the interactive effect of different operating parameters during experimental runs. Analysis of the effects of the ultrasound intensity and the membrane pore size on retention and fouling coefficient demonstrated that the ultrasound intensity affected both the retention and the membrane fouling coefficient (Figs 8-10).

It was found that in case of lower ultrasound intensity, the change of retention was not significant, but higher US intensity significantly decreased the retention. The fouling coefficient significantly decreased by increasing US intensity even in case of lower US intensity. The results indicated that the pore size of the UF membrane does not affect significantly the retention or the fouling coefficient.

\section{CONCLUSIONS}

Following the use of UF coupled with ultrasound with a regenerated cellulose membrane to determine the main fil- tration parameters of a model whey solution, analysis of the fall in flux with time indicated that the cake formation model gave the best correlation to the experimental data. It was shown that an equivalent Reynolds number can be used for calculating the mass transfer coefficient in a batch cell, modeling the effect of ultrasonic mixing on the flux.

The resistances-in-series model also revealed that the increase in resistance during UF is mainly caused by the concentration polarization, while the membrane fouling in the total resistance is negligible. The results show that the ultrasonication effectively decreased the polarization layer resistance.

The statistical analysis of the result showed that higher performance US significantly decrease the membrane fouling caused by concentration polarization, but application of higher US power decreases the retention also. This means that in the practice the ultrasonic power should be optimized to achieve decreased fouling (thus increased flux) with appropriate retention.
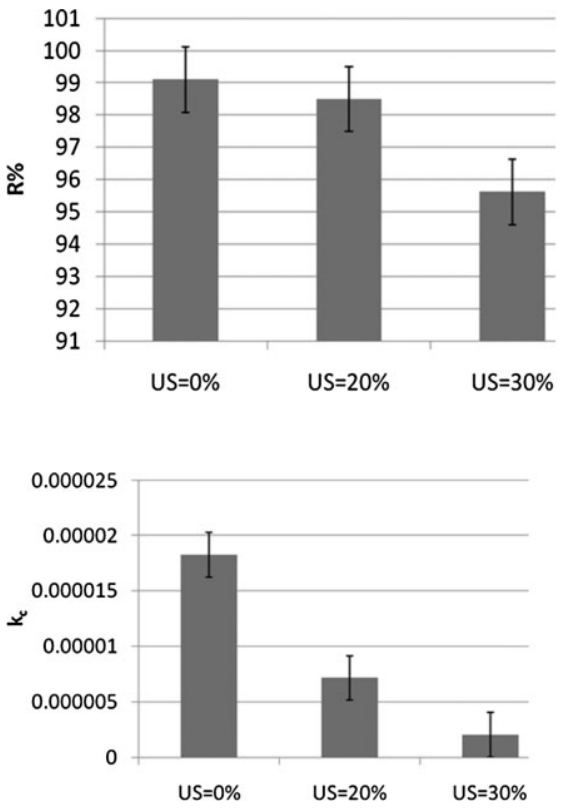
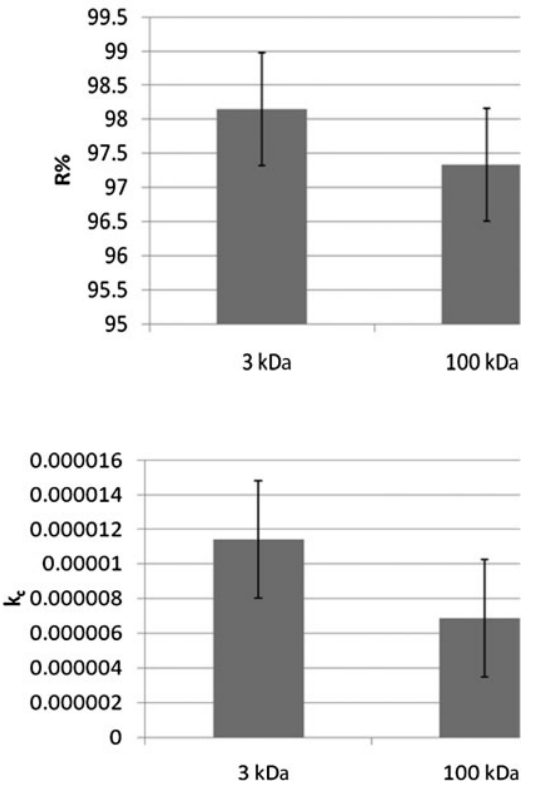

FIG. 9. EFFECT OF ULTRASOUND INTENSITY AND MEMBRANE PORE SIZE ON RETENTION ON THE BASIS OF ANALYSIS OF VARIANCE WITH $P=0.05$ SIGNIFICANT DIFFERENCES 


\section{NOMENCLATURE}

$J \quad-$ flux $\left(\mathrm{L} / \mathrm{m}^{2} / \mathrm{h}\right)$

$J_{0} \quad-$ initial flux

$J_{c}-$ constant flux at the end of the concentration test $\left(\mathrm{L} / \mathrm{m}^{2} / \mathrm{h}\right)$

$J_{W A}-$ water flux after concentration tests $\left(\mathrm{L} / \mathrm{m}^{2} / \mathrm{h}\right)$

$J_{w}-$ water flux $\left(\mathrm{L} / \mathrm{m}^{2} / \mathrm{h}\right)$

$k_{c}$ - fouling coefficient

A - experimental constant

$A_{U S}$ - expert amplitude of ultrasonic transducer mental constant

$K_{c}-$ mass transfer coefficient $(\mathrm{m} / \mathrm{s})$

$b \quad-$ stirring radius $\left(\mathrm{m}^{-1}\right)$

$\omega$ - stirring velocity $(\mathrm{rad} / \mathrm{s})$

$D$ - diffusion coefficient $\left(\mathrm{m}^{2} / \mathrm{s}\right)$

Re - Reynolds number

Sc - Schmidt number

$\eta \quad$ - dynamic viscosity (Pa.s)

$\rho-$ density $\left(\mathrm{kg} / \mathrm{m}^{3}\right)$

$c_{M}$ - concentration on membrane surface (wt \%)

$c_{P}$ - permeate concentration (wt \%)

$c_{F}$ - feed concentration (wt \%)

$R_{M}$ - membrane resistance $\left(\mathrm{m}^{-1}\right)$

$R_{F}$ - fouling resistance $\left(\mathrm{m}^{-1}\right)$

$R_{G}$ - polarization layer resistance $\left(\mathrm{m}^{-1}\right)$

$R_{T}$ - total resistance $\left(\mathrm{m}^{-1}\right)$

$\Delta p$ - transmembrane pressure $(\mathrm{Pa})$

$\eta_{w}$ - viscosity of the water (Pa.s)

$\eta_{w w}-$ viscosity of the wastewater (Pa.s)

\section{ACKNOWLEDGMENTS}

This work was supported by the European Union and co-funded by the European Social Fund. Project title: "Broadening the knowledge base and supporting the longterm professional sustainability of the Research University Centre of Excellence at the University of Szeged by ensuring the rising generation of excellent scientists." Project number: TÁMOP-4.2.2/B-10/1-2010-0012. The authors are grateful for the financial support provided by the project OTKA. Project number: OTKA K105021.

\section{REFERENCES}

ARMFIELD LTD. 2011. Diffusion of a Liquid Apparatus: Instruction Manual for Product Code CERB, Issue 9, March 2011, Armfield Ltd.

BANERJEE, S. and DE, S. 2012. An analytical solution of Sherwood number in a stirred continuous cell during steady state ultrafiltration. J. Memb. Sci. 389, 188-196.
CHAI, X., KOBAYASHI, T. and FUJII, N. 1999.

Ultrasound-associated cleaning of polymeric membranes for water treatment. Sep. Purif. Technol. 15, 139-146.

FENG, H., BARBOSA-CÁNOVAS, G., WEISS, J., eds. 2011. Ultrasound Technologies for Food and Bioprocessing, Food Engineering Series, Springer Science + Business Media, LLC, Berlin, Germany.

HU, B. and SCOTT, K. 2008. Microfiltration of water in oil emulsions and evaluation of fouling mechanism. Chem. Eng. J. 136, 210-220.

JADHAV, S.R., VERMA, N., SHARMA, A. and BHATTACHARYA, P.K. 2001. Flux and retention analysis during micellar enhanced ultrafiltration for the removal of phenol and aniline. Sep. Purif. Technol. 24, 541-557.

KERTÉSZ, S.Z., LÁSZLÓ, Z.S., FORGÁCS, E., SZABÓ, G. and HODÚR, C. 2012. Dairy wastewater purification by vibratory shear enhanced processing. Desalination Water Treat. 37, 1-7.

KOBAYASHI, T., CHAI, X. and FUJII, N. 1999. Ultrasound enhanced cross-flow membrane filtration. Sep. Purif. Technol. $17,31-40$.

KOBAYASHI, T., KOBAYASHI, T., HOSAKA, Y. and FUJII, N. 2003. Ultrasound-enhanced membrane cleaning processes applied water treatments: Influence of sonic frequency on filtration treatments. Ultrasonics 41, 185-190.

KYLLÖNEN, H.M., PIRKONEN, P., NYSTRÖM, M. 2005. Membrane filtration enhanced by ultrasound: A review. Desalination 181, 319-335.

LATT, K. and KOBAYASHI, T. 2006. Ultrasound-membrane hybrid processes for enhancement of filtration properties. Ultrason. Sonochem. 13, 321-328.

MUTHUKUMARAN, S., YANG, K., SEUREN, A., KENTISH, S., ASHOKKUMAR, M., STEVENS, G.W. and GRIESER, F. 2004. The use of ultrasonic cleaning for ultrafiltration membranes in the dairy industry. Sep. Purif. Technol. 39, 99-107.

MUTHUKUMARAN, S., KENTISH, S., LALCHANDANI, S., ASHOKKUMAR, M., MAWSON, R., STEVENS, G.W., KYLLÖNEN, H.M., PIRKONEN, P. and NYSTROM, M. 2005. Membrane filtration enhanced by ultrasound: A review. Desalination 180, 319-335.

NICOLAS, S., BALANNEC, B., BELINE, F. and BARIOU, B. 2000. Ultrafiltration and reverse osmosis of small non-charged molecules: A comparison study of rejection in a stirred and unstirred batch cell. J. Memb. Sci. 164, 141-155.

SANTHANAMA, N. and BAKHSHI, N.N. 1968. New experimental technique to measure ultrasonically induced mixing. J. Acoust. Soc. Am. 43, 377-378.

SCHWARZE, M., LE, D.K., DREWS, A., ARLT, W. and SCHOMÄCKER, R. 2010. Stirred cell ultrafiltration of aqueous micellar TX-100 solutions. Sep. Purif. Technol. 74, 21-27. 